\title{
Spesialisasi Kegiatan Produksi dan Kemitraan Subkontrak pada Klaster Batik Kota Pekalongan
}

\author{
Aulia Dwi Zulhida1 \\ PT. Krinotek Kon, Pontianak, Indonesia
}

\section{Ragil Haryanto}

Departemen Perencanaan Wilayah dan Kota

Fakultas Teknik, Universitas Diponegoro, Semarang, Indonesia

Artikel Masuk : 13 April 2016

Artikel Diterima : 31 Mei 2016

Tersedia Online : 31 Agustus 2016

\begin{abstract}
Abstrak: Kota Pekalongan memiliki 860 usaha industri batik pada tahun 2013 yang berkembang dalam pola spesialisasidan kemitraan subkontrak. Sebagian besar industri batik tidak melakukan seluruh proses produksi sendiri tetapi memberikan kepada industri lain yang memiliki spesialisasi tertentu. Studi bertujuan untuk menentukan spesialisasi kegiatan produksi dan subkontrak kemitraan pada klaster batik Kota Pekalongan. Studi dilakukan dengan menggunakan metode kuantitatif melalui teknik analisis deskriptif kuantitatif. Hasil studi menunjukkan bahwa Pekalongan memiliki mayoritas jenis industri batik cap, yaitu sebesar $82 \%$ dari total industri. Spesialisasi terdiri dari pembatikan, konveksi, dan pembuatan canting. Spesialisasi tersebut berkelompok secara geografis menjadi sebuah sentra karena faktor endowment, seperti pekerja, lahan, dan infrastruktur. Spesialisasi kegiatan produksi juga menjadi salah satu penyebab kemitraan subkontrak di Klaster Batik Kota Pekalongan atau dikenal sebagai faktor speciality subcontracting. Kemitraan subkontrak memberikan dampak negatif dan positif, seperti terjadi ketergantungan subkontraktor dengan prinsipal, efisiensi faktor produksi, dan efisiensi biaya. Hal ini menunjukkan bahwa spesialisasi kegiatan produksi dan kemitraan subkontrak pada klaster batik Kota Pekalongan saling berkaitan.
\end{abstract}

Kata Kunci: kluster batik, Kota Pekalongan, spesialisasi, kemitraan subkontrak

\begin{abstract}
Pekalongan City has 860 batik industries in 2013 whose development underpinned by specialization and subcontracting partnership patterns. Most of the batik industries do not solely proceed the entire production process, rather they set up a subcontracting partnership with the other specialized industries. The study purposed to determine the production specialization and subcontracting partnership in Pekalongan batik cluster. The study completed by using a quantitative method with descriptive quantitative analysis. The results showed that the majority of Pekalongan batik industry is stamping batik, covering $82 \%$ share of the entire batik industries. The specialization consisted of batik production, convection, and canting production. These specializations geographically grouped into subclusters due to endowment factor, such as labor, land, and infrastructure. The specialization of production
\end{abstract}

\footnotetext{
${ }^{1}$ Korespondensi Penulis: PT. Krinotek Kon, Pontianak, Indonesia

Email: aulia.dwi15@pwk.undip.ac.id
} 
also led to subcontracting partnership in the batik cluster which was known as speciality subcontracting. The subcontracting partnership has negative and positive impacts, such as the dependence of the subcontractors to their principals, the efficiency in production factors, and cost efficiency. It shows that the production specialization and subcontracting partnership in Pekalongan batik cluster are mutually interconnected.

Keywords: batik cluster, Pekalongan City, specialization, subcontracting partnership

\section{Pendahuluan}

Usaha Kecil dan Menengah (UKM) memiliki peran yang cukup besar dalam perkembangan ekonomi suatu wilayah. Keberadaan UKM mampu mendorong perkembangan ekonomi dan mengurangi tingkat kemiskinan terkait dengan nilai tambah ekonomi, lapangan kerja, kesempatan kerja, dan aktivitas ekspor (Wattanapruttipaisan, 2002; Radam, Abu, \& Abdullah, 2008; Agyapong, 2010). Namun demikian, perkembangan UKM di negara-negara berkembang sering terhambat oleh kurangnya inovasi, kurangnya keterampilan dan manajemen, ketersediaan sumber daya (Radam et al., 2008; Wattanapruttipaisan, 2002). Di Indonesia, kegiatan UKM memanfaatkan potensi lokal yang ada baik dari sumber daya alam maupun sumber daya manusianya. Penggunaan sumber daya lokal sering kali menjadikan usaha yang dijalankan UKM menjadi sektor unggulan di suatu wilayah. Menurut Perroux (dalam Munir \& Fitanto, 2008) bahwa industri unggulan merupakan penggerak utama dalam pembangunan daerah.

Di Kota Pekalongan terdapat suatu industri yang berkembang menjadi klaster dengan didominasi oleh UKM yang juga menjadi unggulan, yaitu klaster batik Kota Pekalongan. Klaster industri adalah kelompok industri spesifik yang dihubungkan oleh jaringan mata rantai proses penciptaan atau peningkatan nilai tambah, baik melalui hubungan bisnis maupun nonbisnis (Widodo, 2003). Marshall (dalam Amin, 2007) juga mengungkapkan bahwa klaster industri adalah berkumpulnya industri-industri dalam sebuah ruang geografis, dimana manfaat dari klaster industri tidak dinikmati secara pribadi dan mikro oleh sebuah perusahaan, namun dapat dinikmati bersama oleh industri-industri yang berkumpul di dalam klaster. Industri batik menjadi roda perekonomian sebagian masyarakat Pekalongan sejak tahun 1830-an. Namun, industri batik Pekalongan kondisinya tidak selalu stabil.

Sejak ditetapkannya Batik Indonesia sebagai warisan kemanusiaaan untuk budaya lisan dan nonbendawi (Masterpieces of the Oral and Heritage of Humanity) pada tahun 2009, industri batik Indonesia mulai kembali tumbuh pesat termasuk industri di Kota Pekalongan. Menurut data Dinas Perindustrian, Perdagangan, Koperasi, dan UMKM Kota Pekalongan (2013), hingga tahun 2013 jumlah industri batik mencapai 860 industri. Menurut Nurbiajanti (2013), banyaknya jumlah industri batik membuat jumlah tenaga kerja di industri batik mencapai \pm 9.992 orang. Sejak tahun 2009, industri batik Pekalongan terus berkembang hingga tahun 2011. Hal ini menjadikan Kota Pekalongan untuk membranding kotanya sebagai Pekalongan, World's city of Batik karena kekayaan industri batik yang dimiliki. Pada akhir tahun 2014, Kota Pekalongan ditetapkan UNESCO untuk masuk ke dalam jaringan Kota Kretaif Dunia atau World Creative City pada bidang Craft and Folk Arts atau kerajinan dan kesenian tradisional. Predikat ini diberkan karena Pekalongan memiliki banyak sentra yang berakar budaya salah satunya batik.

Fenomena tersebut menujukkan bahwa industri batik di Pekalongan terus tumbuh dan bermunculan pengusaha-pengusaha baru. Banyaknya industri batik yang bermunculan menjadikan adanya spesisalisasi kegiatan produksi yang dilakukan oleh industri-industri. Aiginger dan Rossi-Hansberg (2003) berpendapat bahwa spesialisasi didefinisikan sebagai 
berbagi proses produksi industri dari suatu wilayah. Menurut OECD (dalam Landiyanto, 2005), spesialisasi industri menunjukkan bahwa aktivitas ekonomi pada suatu wilayah dikuasai oleh beberapa industri tertentu. Spesialisasi ini digunakan untuk pembagian kegiatan produksi antar pengusaha sehingga produksi batik menjadi lebih efektif dan efisien.

Spesialisasi juga merupakan salah satu faktor pendorong terbentuknya kemitraan di klaster batik Pekalongan. Kemitraan ini berupa subkontrak. Adapun definisi kemitraan menurut Peraturan Pemerintah Nomor 17 Tahun 2013 adalah kerja sama dalam keterkaitan usaha, baik langsung maupun tidak langsung, atas dasar prinsip saling memerlukan, mempercayai, memperkuat, dan menguntungkan yang melibatkan pelaku usaha mikro, kecil, dan menengah dengan usaha besar. Sementara itu, subkontrak menurut Sjaifudian \& Chotim (1994) merupakan salah satu cara untuk melakukan desentralisasi produksi dengan ataupun tanpa kontrak tertulis yang meminta pihak lain mengolah atau memproses bagian atau keseluruhan suatu produk dengan ketentuan yang mengikat kedua belah pihak (jenis, jumlah, waktu, dan lainnya). Beberapa keuntungan metode subkontrak dalam kehidupan UMKM, di antaranya adanya dukungan teknis untuk proses produksi, dukungan kontrol kualitas, penyediaan peralatan produksi, pelatihan teknis, dan pemasaran (Hayashi dalam Tambunan, 2008). Metode subkontrak antara UKM dengan perusahaan yang lebih besar bermanfaat untuk keberlanjutan UKM terkait dengan akses sumber daya, kualitas produk, desain, inovasi, dan diferensiasi produk (Kumar \& Subrahmanya, 2007; Wattanapruttipaisan, 2002). Ini dikarenakan perusahaan yang lebih besar mampu menjadi sumber modal, memberi jaminan kualitas produk, akses pasar untuk penjualan, dan jangkauan distribusi yang lebih luas (Wattanapruttipaisan, 2002). Kemitraan subkontrak memiliki dampak positif untuk perkembangan UKM (Kumar \& Subrahmanya, 2007; Gakure, Kimemia, \& Waititu, 2014). Kemitraan subkontrak menyangkut hubungan pembayaran dan penawaran dimana UKM berkedudukan sebagai subkontraktor atau penyedia produk atau jasa bagi suatu kegiatan produksi (Kumar \& Subrahmanya, 2007). Namun demikian, hasil penelitian lain juga mengungkapkan bahwa penghambat kemitraan subkontrak antara UKM dengan perusahaan besar menyangkut kualitas bahan baku yang kurang baik, kurangnya pelayanan, konflik kepentingan, inovasi, dan tidak mampunya penyediaan permintaan oleh subkontraktor (Okatch, Mukulu, \& Oyugi, 2011; Nwokocha \& Madu, 2015). Bahkan, Hu, Zheng, \& Wang (2011) mengungkapkan bahwa tidak ada korelasi antara kemitraan subkontrak dan aktivitas usaha.

Berbagai studi mengenai dampak kemitraan subkontrak bagi UKM telah dilakukan. Oleh karena itu, studi ini bertujuan untuk mengetahui spesialisasi kegiatan produksi dan kemitraan subkontrak pada klaster batik Kota Pekalongan. Studi ini berupaya untuk menggali mengenai spesialisasi yang ada dan dimana lokasi dari industri tersebut, apakah lokasinya mengelompok atau tersebar. Selain itu, juga hendak diketahui bagaimana keterkaitan antara spesialisasi kegiatan dengan kemitraan subkontrak serta apa dampak dengan adanya kemitraan subkontrak pada klaster batik Kota Pekalongan.

Secara makro, ruang lingkup wilayah penelitian Kota Pekalongan. Justifikasi pemilihan wilayah studi di Kota Pekalongan karena Pekalongan dikenal dengan klaster batiknya dan industri batik tersebar di hampir seluruh kelurahan. Secara administratif, wilayah Kota Pekalongan dibagi menjadi 4 kecamatan, yaitu Pekalongan Utara, Pekalongan Timur, Pekalongan Barat, dan Pekalongan Selatan. Sementara itu, wilayah studi mikro adalah industri-industri batik atau sentra-sentra batik yang tersebar di masing-masing kecamatan di Kota Pekalongan.

Gambar 1 menunjukkan titik-titik lokasi persebaran industri batik di Kota Pekalongan. Dari peta tersebut terlihat bahwa Kota Pekalongan memiliki lokasi industri batik yang tersebar di seluruh kecamatan di Kota Pekalongan. Namun demikian, terlihat bahwa titik- 


\section{Spesialisasi Kegiatan Produksi dan Kemitraan Subkontrak pada Klaster Batik Kota Pekalongan}

titik industri batik lebih banyak terdapat di Kecamatan Pekalongan Barat dan Pekalongan Selatan.

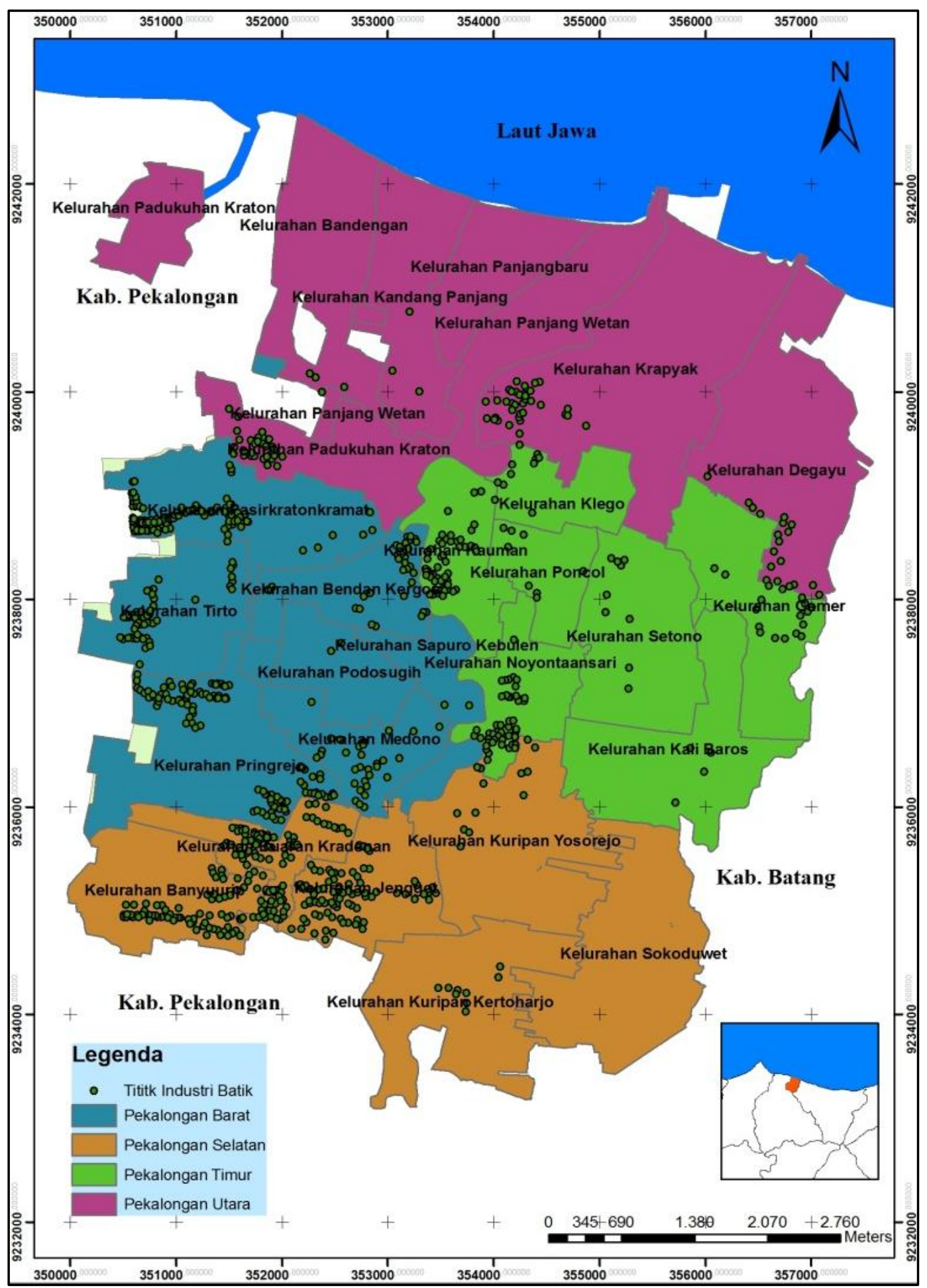

Sumber: Bappeda Kota Pekalongan, 2010 dan Hasil Analisis, 2015

\section{Gambar 1. Peta Wilayah Studi}




\section{Metode Penelitian}

Penelitian tentang spesialisasi kegiatan produksi dan kemitraan subkontrak pada klaster batik Kota Pekalongan menggunakan pendekatan kuantitatif dengan metode kuantitatif dekriptif. Metode kuantitatif deskriptif digunakan untuk menjelaskan atau menggambarkan spesialisasi kegiatan produksi dan kemitraan subkontrak pada klaster batik Kota Pekalongan.

Metode pengumpulan data dilakukan melalui metode pengumpulan data primer dan sekunder. Metode pengumpulan data primer dilakukan dengan menggunakan teknik wawancara, kuesioner, dan observasi lapangan. Metode pengumpulan data tersebut bertujuan untuk mengetahui kondisi klaster batik di Kota Pekalongan, spesialiasi kegiatan produksi batik di Kota Pekalongan, dan kemitraan subkontrak yang ada dalam kehidupan klaster industri batik Pekalongan. Teknik kuesioner dilakukan kepada 90 industri batik di Pekalongan. Responden dipilih berdasarkan kecenderuangan aktivitas yang mayoritas menjadi kegiatan utama di setiap kecamatan, seperti aktivitas pembatikan cap di Pekalongan Selatan, pembatikan tulis di Pekalongan Utara, konveksi di Pekalongan Barat, dan pembuatan canting cap di Pekalongan Timur. Wawancara dilakukan dengan dinas terkait, seperti Dinas Perindustrian, Perdagangan, Koperasi, dan UMKM Kota Pekalongan serta para pengusaha batik untuk mengetahui perkembangan industri batik di Kota Pekalongan. Selain itu, wawancara juga dilakukan kepada 10\% dari total responden yang dari hasil hitungan dan dibagi antara industri yang melakukan produksi sendiri, industri yang melakukan subkontrak, dan pihak subkontraktor. Teknik observasi lapangan dilakukan pada seluruh wilayah yang memiliki industri batik yang cukup dominan untuk melihat proses pembatikan yang terjadi.

\section{Hasil dan Pembahasan}

\section{Karakteristik Klaster Batik Kota Pekalongan}

Industri batik di Kota Pekalongan tidak berkumpul di satu titik, namun tersebar di beberapa titik layaknya menjadi sebuah sentra-sentra. Titik-titik tersebut tersebar di hampir semua wilayah Kota Pekalongan. Sebanyak 50\% industri batik telah ada sekitar 11-20 tahun yang lalu. Sementara itu, sebanyak 50\% lainnya berdiri kurang dari 10 tahun dan lebih dari 20 tahun. Saat ini, sebagian hasil produk batik dari merupakan batik cap. Industri batik cap mendominasi industri batik di Kota Pekalongan, yaitu sebesar $82 \%$ dari total industri yang ada. Hal ini dikarenakan batik cap lebih mudah untuk diproduksi, memerlukan waktu yang relatif lebih singkat dibanding batik tulis, serta harga yang relatif lebih terjangkau.

Pekerja industri batik berasal dari sekitar industri dan memiliki usia yang beragam, yaitu antara 17 hingga 60 tahun. Keterampilan yang dimiliki pekerja didapatkan secara turun temurun dari para leluhur atau orang tua para pekerja. Setiap indsutri batik memiliki rata-rata jumlah pekerja antara 5 hingga 20 pekerja dan didominasi oleh para pekerja lakilaki. Upah pekerja industri batik atau disebut pocokan diberikan seminggu sekali, yaitu setiap hari Kamis dengan jumlah berkisar antara Rp 20.000,00 hingga Rp 75.000,00 per hari atau tergantung pekerjaan yang dilakukan.

\section{Spesialisasi Kegiatan Produksi Batik}

Spesialisasi kegiatan produksi merupakan pembagian kerja antar pelaku usaha sehingga memiliki spesialisasi yang berbeda antar pelaku usaha. Berdasarkan hasil analisis, sebanyak $74 \%$ spesialisasi kegiatan produksi batik merupakan batik cap. Sedangkan persentase spesialisasi kegiatan konveksi hanya 4\%. Gambar 2 menunjukkan proporsi spesialisasi kegiatan produksi batik di Kota Pekalongan. Spesialisasi kegiatan terkonsentrasi 
secara geografis, seperti dalam satu kelurahan yang biasanya akan melakukan kegiatan produksi yang serupa. Hal ini dipengaruhi oleh tenaga ahli yang ada di daerah tersebut.

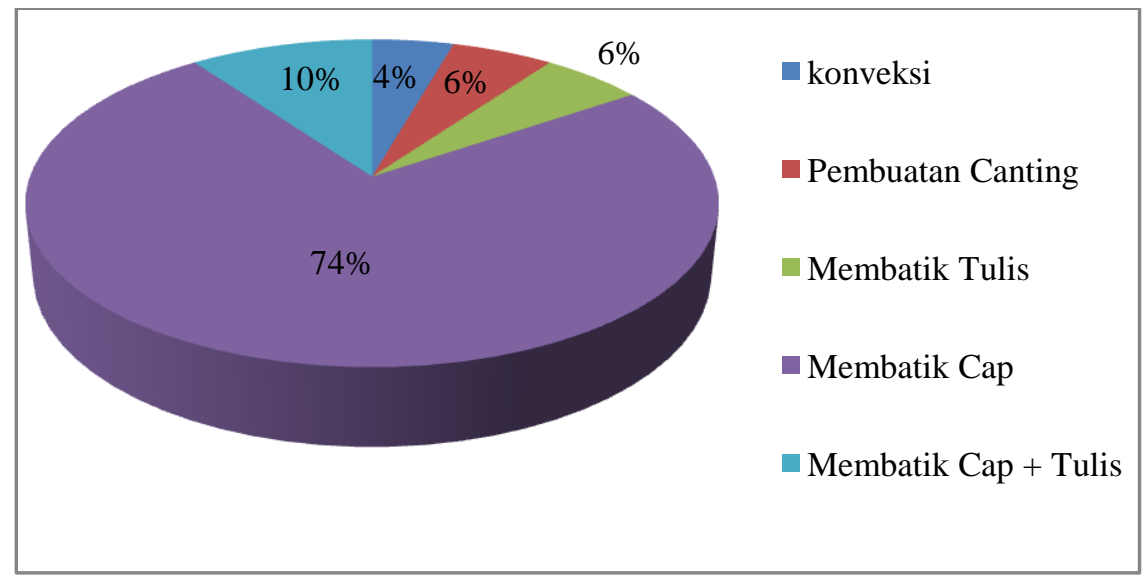

Sumber: Hasil Analisis, 2015

Gambar 2. Persentase Spesialisasi Kegiatan Utama

Setiap spesialisasi kegiatan memiliki ciri khusus dalam hal tenaga kerja dan status pelaku usaha. Kegiatan membatik cap memiliki ciri-ciri bahwa sebagian besar merupakan subkontraktor dan pekerja berjenis kelamin laki-laki. Hal ini dikarenakan pekerjaan ini memerlukan tenaga yang lebih berat dan waktu yang cepat. Sementara itu, membatik tulis memiliki ciri-ciri bahwa pelaku usaha juga merupakan subkontraktor dan pekerja merupakan perempuan. Jenis kegiatan membatik tulis merupakan subkontraktor dan didominasi oleh pekerja perempuan karena memerlukan ketelitian dan kesabaran.

Spesialisasi kegiatan membatik cap dan tulis memiliki karakteristik berupa pengusaha pribadi dan bos dan pekerjanya seimbang antara laki-laki dan perempuan. Spesialisasi konveksi batik merupakan subkontraktor dan didominasi oleh pekerja perempuan. Konveksi batik muncul karena adanya permintaan tentang jasa penjahitan untuk melakukan proses setelah menjadi kain batik sehingga sebagian besar konveksi batik merupakan subkontraktor. Mayoritas pekerja pada konveksi batik adalah perempuan karena keterampilan menjahit yang banyak dimiliki oleh perempuan. Sementara itu, dalam spesialisasi pembuatan canting tidak ada istilah bos atau subkontraktor. Seluruh pekerja merupakan laki-laki karena memerlukan banyak tenaga dan telah secara turun temurun dilakukan oleh laki-laki. Secara lebih jelas mengenai perbedaan produksi klaster batik di Kota Pekalongan dapat dilihat di Tabel 1.

Tabel 1. Spesialisasi Kegiatan Produksi Klaster Batik di Kota Pekalongan

\begin{tabular}{|c|c|c|}
\hline Spesialisasi & Ciri-ciri & Lokasi \\
\hline Membatik Cap & $\begin{array}{l}\text { - Subkontraktor } \\
\text { - Laki-laki }\end{array}$ & $\begin{array}{l}\text { Kelurahan Banyuurip, Jenggot, Buaran } \\
\text { Kradenan, Pringrejo, Tirto, Pasirkratonkramat, } \\
\text { Padukuhan Kraton, Krapyak }\end{array}$ \\
\hline Membatik Tulis & $\begin{array}{l}\text { - Subkontraktor } \\
\text { - Perempuan }\end{array}$ & Kelurahan Bandengan dan Gamer \\
\hline $\begin{array}{l}\text { Membatik Cap dan } \\
\text { Tulis }\end{array}$ & $\begin{array}{l}\text { - Pribadi dan Bos } \\
\text { - Laki-laki dan Perempuan }\end{array}$ & Kelurahan Kauman dan Bendan Kergon, Klego \\
\hline
\end{tabular}




\begin{tabular}{lll}
\hline \multicolumn{1}{c}{ Spesialisasi } & \multicolumn{1}{c}{ Ciri-ciri } & \multicolumn{1}{c}{ Lokasi } \\
\hline Konveksi & $\bullet$ Subkontraktor & Kelurahan Medono \\
Pembuatan Canting & $\bullet$ Perempuan & Kribadi \\
& $\bullet$ Laki-laki & Kelurahan Noyontaansari \\
\hline Sumber: Hasil Analisis, 2015 &
\end{tabular}

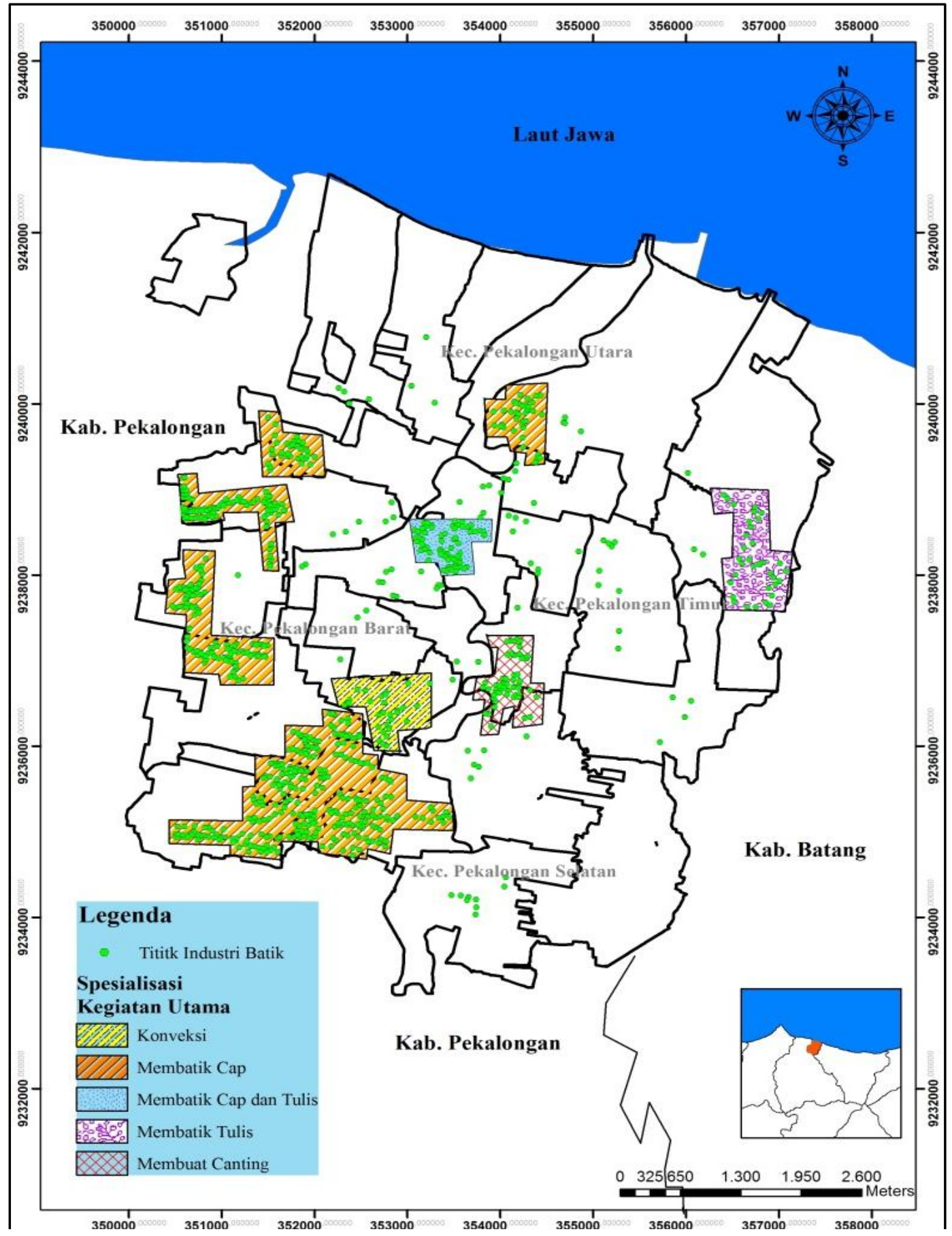

Sumber: Hasil Analisis, 2015

Gambar 3. Peta Spesialisasi Kegiatan Produksi 
Gambar 3 menunjukkan peta lokasi spesialisasi kegiatan produksi batik di Kota Pekalongan. Peta di Gambar 3 menunjukkan bahwa setiap spesialisasi melakukan konsentrasi secara geografis menjadi sebuah sentra. Kegiatan membatik cap mendominasi spesialisasi produksi batik di Kota Pekalongan karena ditemukan di 3 kecamatan di Kota Pekalongan, yaitu Kecamatan Pekalongan Selatan, Pekalongan Barat, dan Pekalongan Utara dengan rincian kelurahan sebagaimana terlihat di Tabel 1.

Hasil kuesioner menunjukkan bahwa pengelompokan disebabkan oleh adanya beberapa faktor tertentu, seperti keterkaitan dengan industri lain, mendekati pekerja, lahan yang luas, dan penggunaan insfrastruktur bersama. Kegiatan produksi yang berada di pusat kota cenderung berkelompok karena penggunaan infrastruktur bersama, seperti IPAL. Sementara itu, untuk kegiatan produksi di pinggiran kota cenderung berkelompok karena memerlukan lokasi yang luas dan harga lahan yang relatif murah. Jika dilihat dari jenis kegiatan produksinya, kegiatan membatik tulis, pembuatan canting, dan konveksi lebih memilih untuk berkelompok karena faktor pekerja dan keterkaitan dengan industri lain. Adapun besarnya proporsi masing-masing faktor yang mempengaruhi pemilihan lokasi dalam klaster batik terlihat di Gambar 4.

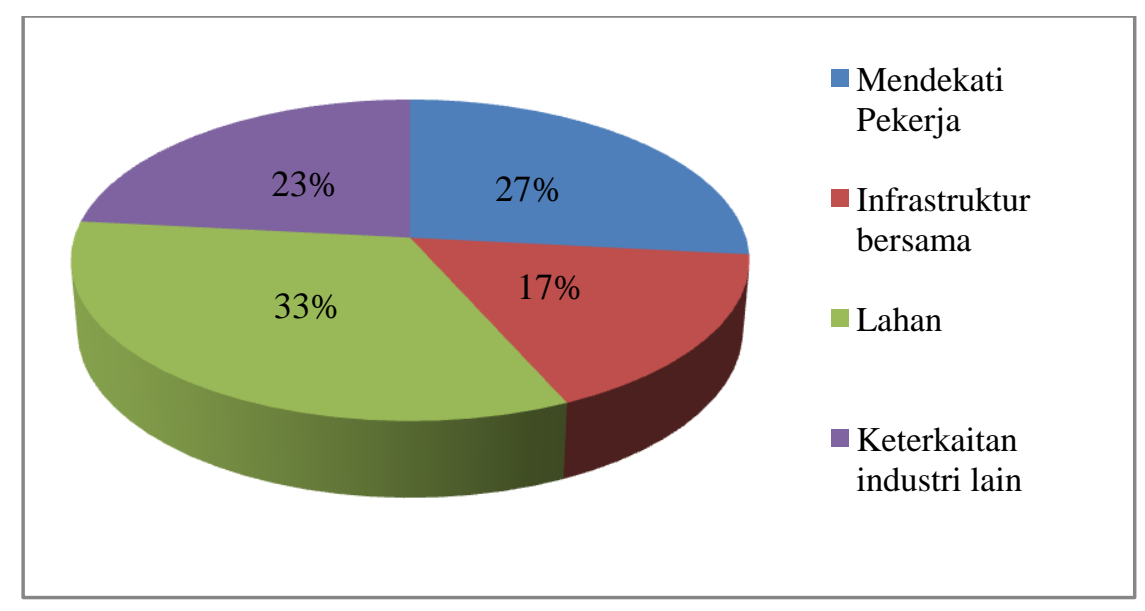

Sumber: Hasil Analisis, 2015

\section{Gambar 4. Persentase Faktor Pemilihan Lokasi dalam Klaster Batik}

\section{Kemitraan Subkontrak dalam Kehidupan Klaster Batik Kota Pekalongan}

\section{Kemitraan Subkontrak}

Salah satu ciri sebuah klaster adalah memiliki keterkaitan antar industri di dalamnya. Begitu pula yang terjadi dalam klaster batik Kota Pekalongan yang memiliki keterkaitan antarindsutri terutama dalam hal kegiatan produksi. Bentuk keterkaitan yang terjadi berupa kemitraan subkontrak. Dalam kemitraan subkontrak klaster batik Kota Pekalongan terdapat 2 pihak yang terlibat, yaitu prinsipal atau disebut bos dan subkontraktor atau disebut buruh di Klaster batik Kota Pekalongan. Peran prinsipal atau bos, yaitu sebagai pemberi order kepada subkontraktor untuk melakukan kegiatan produksi sesuai spesialisasinya. Sedangkan subkontraktor melakukan permintaan sesuai permintaan bos. Subkontraktor di klaster batik Kota Pekalongan terdiri dari subkontraktor pembatik (cap dan tulis) serta subkontraktor konveksi atau penjahitan. 
Hubungan subkontrak yang ada di klaster batik Kota Pekalongan merupakan hubungan industrial subcontracting, dimana pihak subkontraktor hanya mengerjakan proses tertentu dan proses selanjutya akan dilanjutkan oleh prinsipal. Dalam klaster batik Kota Pekalongan, prinsipal memberi permintaan kepada subkontraktor batik cap. Selanjutnya, subkontraktor mengerjakan permintaan dan mengembalikan ke subkontraktor dalam bentuk kain batik. Prinsipal akan melakukan penjahitan sendiri namun ada pula yang memburuhkan kembali ke subkontraktor konveksi, dan mengembalikan ke prinsipal setelah menjadi pakaian siap jual. Biaya yang dibutuhkan untuk prinsipal memburuhkan kepada subkontraktor antara lain, biaya subkontraktor membatik sekitar Rp 30.000,00 hingga Rp $35.000,00$ dan subkontraktor konveksi sebesar Rp 10.000,00. Keuntungan yang diperoleh subkontraktor dari kemitraan subkontrak ini sebesar $15-30 \%$ dari harga yang dibayar oleh prinsipal.

Pola subkontrak di Klaster Batik Kota Pekalongan terdiri atas pola terikat dan pola bebas. Pola terikat menunjukkan bahwa subkontraktor hanya boleh mengerjakan permintaan dari satu bos dan tidak boleh menerima permintaan yang lainnya. Sedangkan dalam pola bebas, subkontraktor diperbolehkan untuk menerima permintaan dari berbagai bos. Adapun motivasi kemitraan subkontraktor pada klaster batik Kota Pekalongan salah satunya adanya spesialisasi kegiatan produksi atau speciality subcontracting. Ketidakmampuan para pelaku industri untuk menyediakan faktor produksi secara lengkap menjadikan munculnya pola subkontrakuntuk memenuhi faktor produksi seperti bahan baku dan modal (subkontraktor), lahan, dan tenagakerja (prinsipal).

\section{Mekanisme Kehidupan Klaster Batik}

Menurut Untari (2005) adanya kemitraan usaha dapat dilihat dari mekanisme kehidupan klaster industri kecil, mulai dari kegiatan input, proses, dan output dalam aktivitas produksi. Hal ini sama halnya dengan aktivtias pengadaan bahan baku yang mencakup aktivitas produksi sebagai input dan aktivitas pemasaran barang produksi sebagai output. Adapun runtutan aktivitas dalam kehidupan klaster batik di Kota Pekalongan terjabarkan sebagai berikut:

a. Aktivitas Pengadaan Bahan Baku

Bahan baku utama berupa kain, pewarnaan lilin atau malam, serta tembaga sebagai bahan baku canting. Sebanyak $70 \%$ bahan baku kain didapatkan dari dalam kota, baik dari pabrik di Kota Pekalongan maupun supplier atau agen. Sementara itu, sebanyak 30\% lainnya berasal dari luar kota, seperti Kota Solo. Adapun bahan baku lilin atau malam diperoleh dari toko obat yang ada di Kota Pekalongan, seperti toko obat di Kelurahan Banyurip, Buaran Kradenan, Kauman, serta Jalan Hayam Wuruk. Bahan baku tembaga untuk pembuatan canting sebagian besar dari pabrik yang ada di Tegal. Adapun peta lokasi jaringan pasokan bahan baku di klaster batik Kota Pekalongan terlihat di Gambar 5.

\section{b. $\quad$ Aktivitas Produksi}

Aktivitas produksi batik di Kota Pekalongan dibagi dalam beberapa tahapan, meliputi tahapan penyiapan kain, penggambaran motif, pembatikan, pewarnaan, pencucian, konveksi, dan pengepakan. Sebagian besar proses produksi batik di Kota Pekalongan menggunakan sistem subkontrak. Adapun jenis subkontraktor di Kota Pekalongan, meliputi subkontraktor membatik cap, membatik tulis, dan subkontraktor konveksi. Subkontraktor membatik biasanya melakukan proses dari penggambaran motif hingga pencucian (menghilangkan malam batik). Sementara itu, untuk subkontraktor pada kegiatan konveksi hanya melakukan proses penjahitan kain batik menjadi batik siap pakai, baik atasan, hem, longdress, daster, celana hingga seprei. 


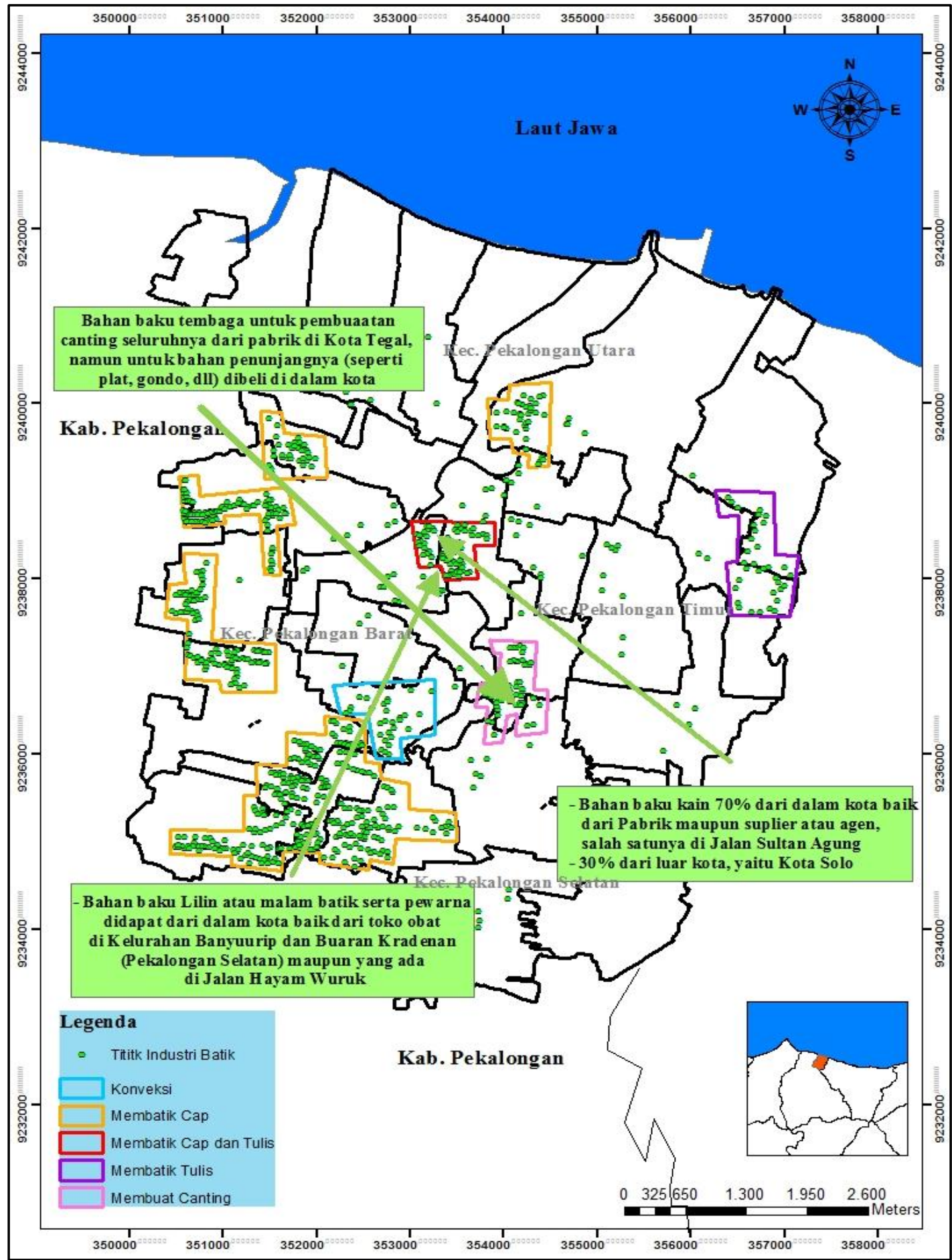

Sumber: Hasil Analisis, 2015

\section{Gambar 5. Peta Jaringan Pasokan Bahan Baku Klaster Batik Kota Pekalongan}

Gambar 6 menunjukkan peta jaringan subkontraktor. Dari peta jaringan subkontraktor di Gambar 6, terlihat bahwa buruh atau subkontraktor batik cap banyak yang berada di Pekalongan Barat dan Selatan, seperti Kelurahan Banyuurip, Jenggot, Buaran Kradenan, Padukuhan Kraton, Tirto, serta Pasirkratonkramat. Subkontraktor untuk batik 
tulis di Kota Pekalongan berada di Kelurahan Gamer dan Bandengan, dan adapula yang melakukan permintaan ke Kecamatan Wiradesa, Kabupaten Pekalongan. Sementara itu, subkontraktor untuk kegiatan konveksi berada di Kelurahan Medono yang terletak di dalam kota. Selain itu, adapula yang memburuhkan konveksi ke Kabupaten Pekalongan tepatnya di Wonopringgo. Ini dikarenakan harga yang relatif lebih murah.

Pelaku usaha pembuatan canting yang terdapat di Kelurahan Noyontaansari. Usaha pembuatan canting di Kelurahan Noyontaansari melakukan produksi rutin dan tidak mengenal istilah juragan dan subkontraktor. Meskipun tidak ada pesanan, pelaku usaha di Kelurahan Noyontaansari tetap melakukan produksi untuk dijual atau dipasarkan sendiri. Karena sifatnya yang rutin berproduksi. Disamping itu, adapula yang melakukan produksi karena permintaan atau pesanan. Sebagian besar pemesan canting berasal dari dalam Kota Pekalongan, namun juga ada yang berasal dari luar kota, seperti Kabupaten Pekalongan, Cirebon, Riau, Bandung, Bali, dan lainnya.

\section{c. $\quad$ Aktivitas Distribusi Pemasaran}

Aktivitas distribusi pemasaran produk pada industri batik di Kota Pekalongan berasal dari pelaku usaha individu, subkontraktor, dan juragan. Untuk subkontraktor, aktivitas distribusi hasil produksi langsung diambil atau diantar ke juragan atau pengorder. Sedangkan untuk pelaku usaha individu maupun juragan yang memasarkan produk sendiri, pemasaran produk dilakukan langsung di toko milik pribadi serta ditawarkan atau didistribusikan ke pengusaha lain atau toko lain yang berada di luar kota. Secara lebin rinci, jaringan aktivitas produksi batik di Kota Pekalongan dapat digambarkan dengan jelas melalui pemetaan jaringan aktivitas produksi batik yang terdiri dari input, proses dan output produksi pada Tabel 2 dan Gambar 7.

Tabel 2. Jaringan Aktivitas Produksi Batik Kota Pekalongan

\begin{tabular}{|c|c|c|}
\hline Keterangan & Kegiatan & Lokasi \\
\hline \multirow[t]{2}{*}{$\begin{array}{l}\text { Input (Bahan } \\
\text { Baku) }\end{array}$} & Kain & $\begin{array}{l}\text { - Dalam Kota: Dari Juragan, Pabrik di dalam Kota } \\
\text { Pekalongan Agen/toko di Jalan Sultan Agung } \\
\text { - Luar Kota: Solo }\end{array}$ \\
\hline & $\begin{array}{l}\text { Pewarna dan Lilin/ } \\
\text { malam }\end{array}$ & $\begin{array}{l}\text { Agen: Kelurahan Banyuurip, Buaran Kradenan, Kauman, } \\
\text { dan Jalan Hayam wuruk }\end{array}$ \\
\hline \multirow[t]{5}{*}{ Proses } & Pembuatan Canting & Pengrajin: Kelurahan Noyontaansari \\
\hline & Penyedia Kain & $\begin{array}{l}\text { Bos/ Juragan: Klego, Kauman, Bendan Kergon, Krapyak, } \\
\text { Buaran Kradenan, }\end{array}$ \\
\hline & $\begin{array}{l}\text { Pembatikan (dari } \\
\text { penggambaran motif }\end{array}$ & $\begin{array}{l}\text { - Individu: Kauman, Bendan Kergon, Banyuurip, Buaran } \\
\text { Kradenan, Jenggot }\end{array}$ \\
\hline & $\begin{array}{l}\text { hingga } \\
\text { pelorodan/pencucian) }\end{array}$ & $\begin{array}{l}\text { - Subkontraktor Cap: Padukuhan Kraton, Pasirkratonkramat, } \\
\text { Tirto, Banyuurip, Buaran Kradenan, Jenggot, Pringrejo } \\
\text { - Subkontraktor Tulis: Gamer dan Bandengan (dalam Kota), } \\
\text { Wiradesa (Kab. Pekalongan) }\end{array}$ \\
\hline & Konveksi & $\begin{array}{l}\text { - Subkontraktor Konveksi: Medono (dalam Kota), } \\
\text { Wonopringgo (Kab. Pekalongan) }\end{array}$ \\
\hline \multirow[t]{4}{*}{ Output } & $\begin{array}{l}\text { Distribusi Pemasaran } \\
\text { di Toko pribadi }\end{array}$ & $\begin{array}{l}\text { - Grosir Setono, Pasar Banjarsari, IBC, Toko-toko di } \\
\text { sepanjang jalan Kota Pekalongan (Jalan Karya Bakti, Jalan } \\
\text { Urip Sumoharjo, Jalan Gatot Subroto, dll) }\end{array}$ \\
\hline & Distribusi Pemasaran & Solo, Jogja, Jakarta, Surabaya, Semarang, Sulawesi, \\
\hline & Ke luar Kota & Kalimantan \\
\hline & Konsumen Akhir & $\begin{array}{l}\text { Pekalongan, Solo, Jogja, Jakarta, Surabaya, Semarang, } \\
\text { Sulawesi, Kalimantan }\end{array}$ \\
\hline
\end{tabular}

Sumber: Hasil Analisis, 2015 


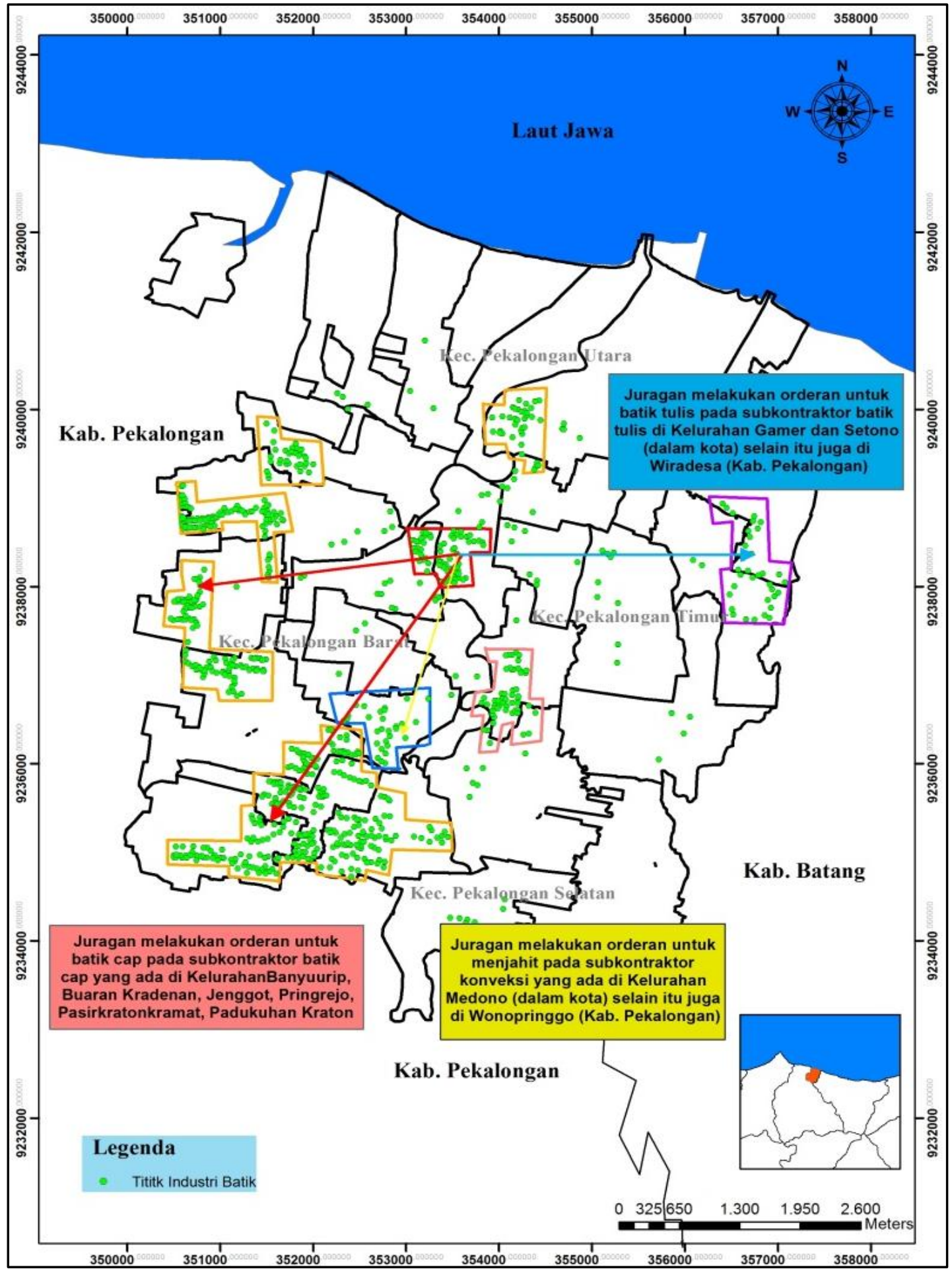

Sumber: Hasil Analisis, 2015

Gambar 6. Peta Jaringan Subkontraktor Klaster Batik Kota Pekalongan 


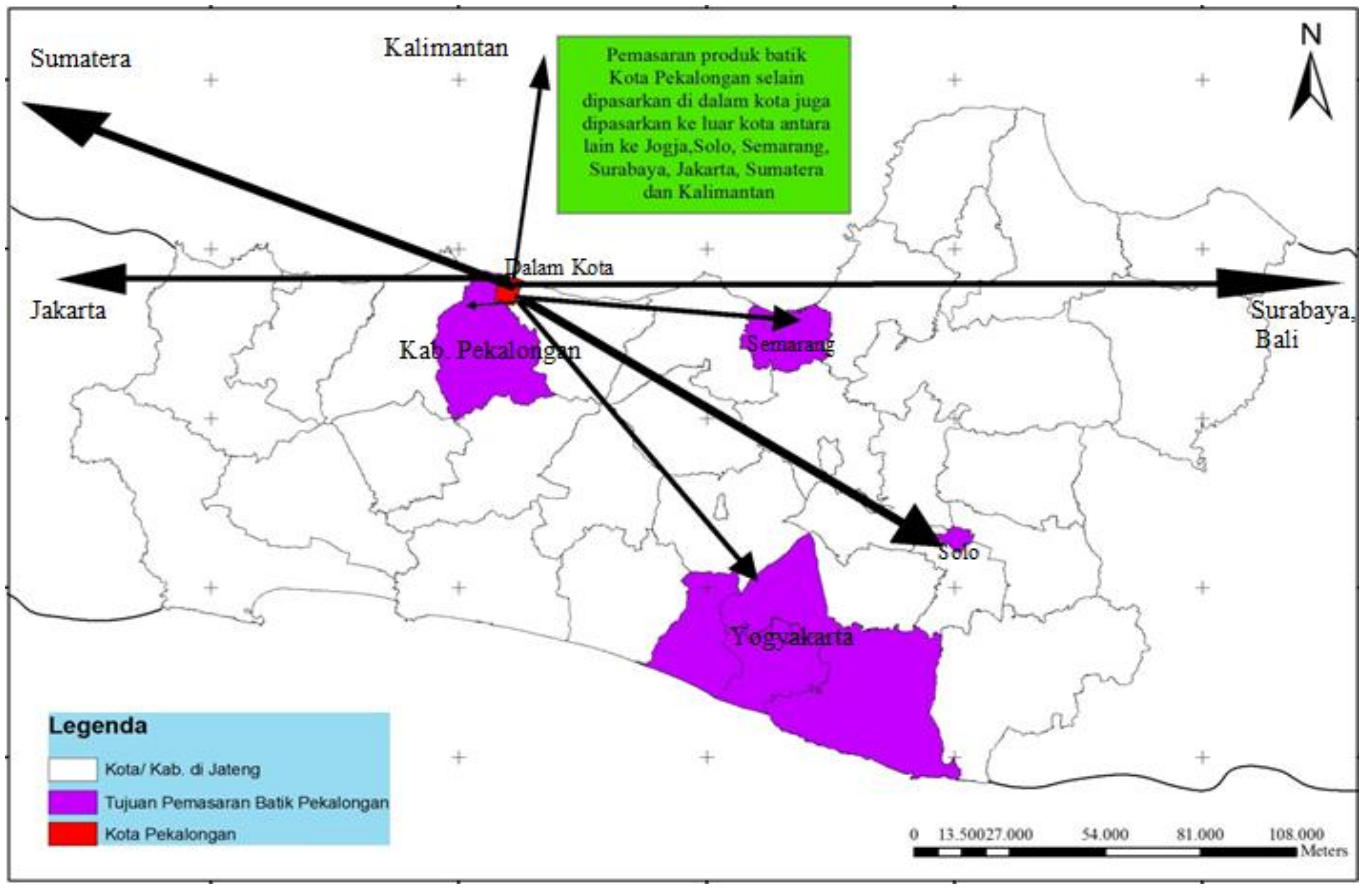

Sumber: Hasil Analisis, 2015

Gambar 7. Peta Jaringan Distribusi Pemasaran Industri Batik Kota Pekalongan

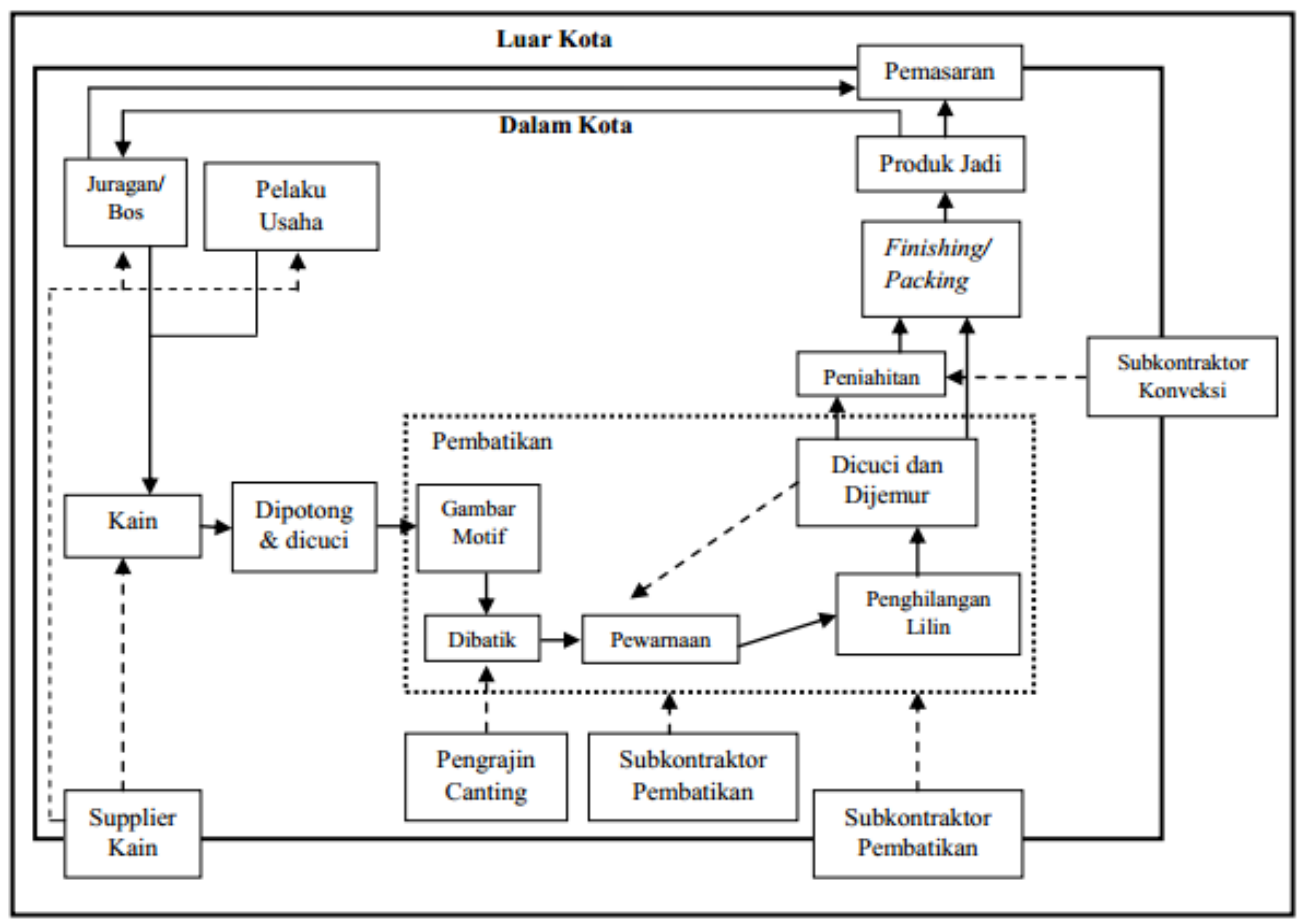

Sumber: Hasil Analisis, 2015

Gambar 8. Mekanisme Kehidupan Klaster Batik Kota Pekalongan 
Gambar 8 menunjukkan mekanisme kehidupan klaster batik Kota Pekalongan secara keseluruhan. Dari diagram pada Gambar 8 diketahui bahwa mekanisme kehidupan klaster batik di Kota Pekalongan merupakan proses produksi batik mulai dari memperoleh bahan baku hingga proses pemasaran hasil produksi. Kemitraan subkontrak merupakan bagian dari kehidupan klaster batik Kota Pekalongan dengan konsentrasi pada aktivitas produksi. Kemitraan subkontrak pada aktivitas produksi terjadi karena ketidakmampuan prinsipal atau bos untuk melakukan proses produksi dan ketidakmampuan subkontraktor untuk memperoleh bahan baku. Selain itu, kemitraan subkontrak juga terjadi karena adanya spesialisasi kegiatan. Hal ini menunjukkan bahwa salah satu faktor pendorong terjadinya kemitraan subkontrak adalah speciality subcontracting atau adanya spesalisasi tertentu dari setiap industri dalam proses produksi batik.

Adanya kemitraan subkontrak memiliki dampak positif maupun negatif dalam klaster batik Kota Pekalongan. Beberapa dampak negatif yang timbul, antara lain munculnya ketergantungan subkontraktor dengan prinsipal karena pihak subkontraktor melakukan proses produksi jika terdapat permintaan dari pihak prinsipal dan kesamaan motif dengan industri lain karena kemitraan subkontrak ini terkadang tidak membatasi subkontraktor untuk bermitra dengan siapa saja. Sementara itu, dampak positif dari kemitraan subkontrak baik untuk prinsipal maupun subkontraktor, yaitu adanya efisiensi faktor produksi (bahan baku, tenaga kerja, sarana prasarana, dan lainnya), biaya produksi, serta pasar. Efisiensi faktor produksi dilihat dalam hal pengadaan bahan baku. Hal ni dikarenakan sebagian besar subkontraktor merupakan pengusaha kecil sering kali terjadi permasalahan tentang bahan baku dan modal. Subkontraktor tidak memiliki cukup modal untuk membeli bahan baku utama, yaitu kain mori. Sedangkan prinsipal atau bos yang cenderung berada di pusat kota tidak memiliki tempat yang cukup untuk melakukan produksi secara mandiri. Oleh karena itu, kemitraan subkontrak mendorong terjadinya kehidupan yang saling melengkapi dalam hal faktor produksi antara prinsipal dan subkontraktor di klaster batik Kota Pekalongan. Dampak positif lainnya adalah efisiensi biaya produksi. Biaya untuk melakukan produksi sendiri dan dengan subkontrak hampir sama serta pemasaran produk dimana subkontraktor tidak perlu memikirkan pemasaran hasil produk mereka karena produk yang sudah jadi langsung diberikan kepada prinsipal. Prinsipal memiliki toko pribadi atau sudah memiliki pasar tersendiri untuk memasarkan produk tersebut baik di dalam kota maupun luar kota Pekalongan. Kondisi ini sesuai dengan pendapat Gakure et al. (2014), Kumar \& Subrahmanya (2007), dan Wattanapruttipaisan (2002) yang menunjukkan bahwa kemitraan subkontrak memiliki dampak positif bagi perkembangan UKM karena terdapat suatu hubungan yang saling melengkapi antar industri yang terlibat terutama dalam hal modal, penyediaan bahan baku, dan pasar.

\section{Kesimpulan}

Spesialisasi kegiatan produksi dan kemitraan subkontrak pada klaster batik Kota Pekalongan saling berkaitan. Spesialisasi kegiatan dalam industri batik berupa spesialisasi pembatikan cap, pembatikan tulis, pembatikan tulis dan cap, konveksi dan pembuatan canting. Spesialisasi ini mengelompok dan membentuk sebuah sentra karena faktor endowment, meliputi lahan, tenaga kerja, infrastruktur,dan lainnya yang dimiliki oleh kawasan tersebut. Salah satu faktor pendorong terjadinya kemitraan subkontrak antara lain speciality subcontracting yang berarti bahwa terjadinya subkontrak karena adanya spesalisasi tertentu dari setiap industri dalam proses produksi batik. Selain itu, juga dikarenakan adanya ketidakmampuan prinsipal untuk melakukan proses produksi secara keseluruhan dan ketidakmapuan subkontraktor untuk menyediakan bahan baku. Adanya kemitraan subkontrak ternyata berdampak berdampak positif dan negatif baik untuk prinsipal maupun subkontraktor. Dampak negatif berupa ketergantungan subkontraktor 
terhadap prinsipal atau bos dan kesamaan motif antara satu industri dengan yang lainnya. Sedangkan dampak positifnya adalah efisiensi faktor produksi, efisiensi biaya, dan pemasaran produk.

\section{Daftar Pustaka}

Agyapong, D. (2010). Micro, small and medium enterprises' activities, income level and poverty reduction in Ghana - A synthesis of related literature. International Journal of Business and Management, 5(12), 196205.

Aiginger, K., \& Rossi-Hansberg, E. (2006). Specialization dan concentration: A note on theory and evidence. Empirica, 33, 255-266. doi:10.1007/s10663-006-9023-y.

Amin, A. (2007). Kemitraan usaha dalam klaster industri kerajinan anyaman di Kabupaten Tasikmalaya (Unpublished undergraduated thesis). Jurusan Perencanaan Wilayah dan Kota, Fakultas Teknik Universitas Diponegoro, Semarang.

Dinas Perindustrian, Perdagangan, Koperasi, dan UMKM Kota Pekalongan. (2013). Data industri di Kota Pekalongan tahun 2013. Kota Pekalongan: Disperindagkop Kota Pekalongan.

Gakure, R. W., Kimemia, P. N., \& Waititu, G. A. (2014). Influence of subcontract offering on the performance of manufacturing micro and small enterprises in Kenya. IOSR Journal of Humanities and Social Science, 19(1), 37-46.

Hu, Z., Zheng, J., \& Wang, J. (2011). Impact of industrial linkages on firm performance in Chinese development zones, Yangtze River Delta, Jiangsu Province, China. The Chinese Economy, 44(2), 78-105. doi:10.2753/1097-1475440205.

Kumar, R. S., \& Subrahmanya, B. (2007). Subcontracting relationships of Indian SMEs with global TNCs: Do SMEs gain? How? Journal of Asian Economics, 5, 2-35.

Landiyanto, E. A. (2005). Konsentrasi spasial industri manufaktur: Tinjauan empiris di Kota Surabaya. Jurnal Ekonomi dan Pembangunan Indonesia, 5(2), 75-90. doi:10.21002/jepi.v5i2.124.

Munir, R., \& Fitanto, B. (2008). Pengembangan ekonomi lokal partisipatif: Masalah, kebijakan dan panduan pelaksanaan kegiatan. Jakarta: Local Governance Support Program (LGSP).

Nurbiajanti, S. (2013). Dari batik Pekalongan mendunia. Retrieved from http://travel.kompas.com/read/2013/07/17/1758369/Dari.Batik.Pekalongan.Mendunia.

Nwokocha, V. C., \& Madu, I. A. (2015). Influence of subcontracting constraints on the performance of manufacturing industries in Nigeria. Production \& Manufacturing Research, 3(1), 343-354. doi:10.1080/21693277.2015.1102101.

Okatch, B. A., Mukulu, E., \& Oyugi, L. (2011). Constraints to subcontracting arrangements between SMEs and large firms in the motor vehicle industry in Kenya. International Journal of Business and Social Science, 2(15), 208-223.

Radam, A., Abu, M. L., \& Abdullah, A. M. (2008). Technical efficiency of small and medium enterprise in Malaysia: A stochastic frontier production model. International Journal of Economics and Management, 2(2), 395-408.

Republik Indonesia. (2013). Peraturan Pemerintah Republik Indonesia Nomor 17 Tahun 2013 tentang Pelaksanaan Undang-Undang Nomor 20 Tahun 2008 tentang Usaha Mikro, Kecil, dan Menengah. Jakarta. Indonesia: Sekretariat Negara Republik Indonesia.

Sjaifudian, H., \& Chotim, E. E. (1994). Dimensi strategi pengembangan usaha kecil: Subkontrak pada industri garmen batik. Bandung: AKATIGA.

Tambunan, T. (2008). Foreign direct investment, local small and medium enterprises and technology transfer in developing countries: A story from Indonesia. SSRN Electronic Journal, June. doi:10.2139/ssrn.1141543.

Untari, R. (2005). Pola pertumbuhan klaster industri kecil Indonesia (Unpublished doctoral dissertation). Program Studi Teknik dan Manajemen Industri, Fakultas Teknik Institut Tekonologi Bandung, Bandung.

Wattanapruttipaisan, T. (2002). SME subcontracting as a bridgehead to competitiveness: An assessment of supply-side capabilities and demand-side requirements. Asia-Pacific Development Journal, 9(1), 65-87. 


\section{Spesialisasi Kegiatan Produksi dan Kemitraan Subkontrak pada Klaster Batik Kota Pekalongan}

Widodo, A. (2003). Pengembangan klaster industri unggulan daerah. Jakarta: Pusat Pengkajian Kebijakan Teknologi Pengembangan Unggulan Daerah dan Peningkatan Kapasitas Masyarakat, Badan Pengkajian dan Penerapan Teknologi (BPPT). 